\title{
HA H4
}

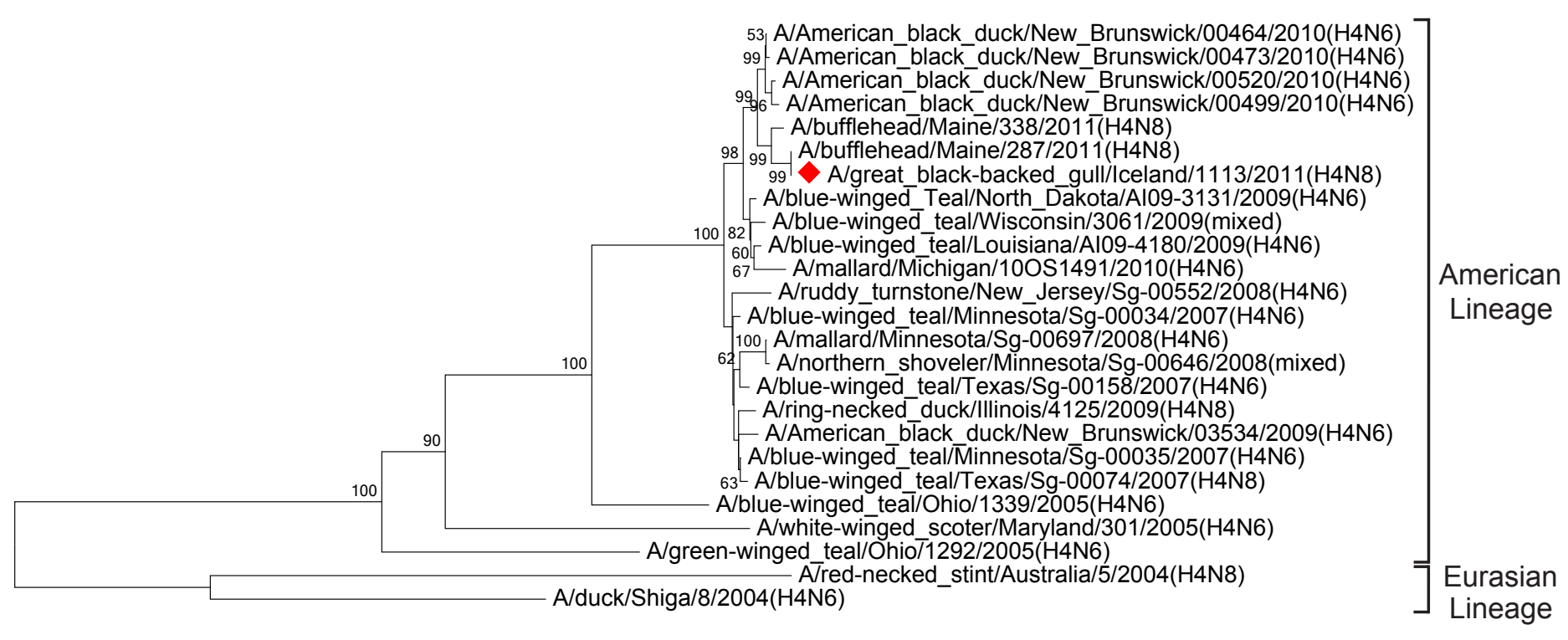

